University of Wollongong

Research Online

Faculty of Science - Papers (Archive)

Faculty of Science, Medicine and Health

$1-1-2004$

\title{
An assessment of five Australian Polychaetes and Bivalves for use in whole-sediment toxicity tests: toxicity and accumulation of Copper and Zinc from water and sediment
}

C K. King

CSIRO Energy Technology

M C. Dowse

CSIRO Energy Technology

S L. Simpson

CSIRO Energy Technology, stuart.simpson@csiro.au

D F. Jolley

University of Wollongong, djolley@uow.edu.au

Follow this and additional works at: https://ro.uow.edu.au/scipapers

Part of the Life Sciences Commons, Physical Sciences and Mathematics Commons, and the Social and Behavioral Sciences Commons

\section{Recommended Citation}

King, C K.; Dowse, M C.; Simpson, S L.; and Jolley, D F.: An assessment of five Australian Polychaetes and Bivalves for use in whole-sediment toxicity tests: toxicity and accumulation of Copper and Zinc from water and sediment 2004, 314-323.

https://ro.uow.edu.au/scipapers/4326

Research Online is the open access institutional repository for the University of Wollongong. For further information contact the UOW Library: research-pubs@uow.edu.au 


\title{
An assessment of five Australian Polychaetes and Bivalves for use in whole- sediment toxicity tests: toxicity and accumulation of Copper and Zinc from water and sediment
}

\begin{abstract}
The suitability of two polychaete worms, Australonereis ehlersi and Nephtys australiensis, and three bivalves, Mysella anomala, Tellina deltoidalis, and Soletellina alba, were assessed for their potential use in whole-sediment toxicity tests. All species except A. ehlersi, which could not be tested because of poor survival in water-only tests, survived in salinities ranging from $18 \%$ o to $34 \%$ o during the 96 -hour exposure period. No mortality was observed in any of the species exposed to sediment compositions ranging from $100 \%$ silt to $100 \%$ sand for 10 days, thus demonstrating the high tolerance of the five species to a wide range of sediment types. All species showed decreased survival after exposure to highly sulfidic sediments in 10-day whole-sediment tests. In 96-hour water-only tests, survival decreased, and copper accumulation in body tissues increased with exposure to increasing copper concentration for all species except A. ehlersi, which again could not be tested because of its poor survival in the absence of sediment. $\mathrm{S}$. alba and T. deltoidalis were the most sensitive species to aqueous copper (LC50s of 120 and $150 \mu \mathrm{g}$ $\mathrm{Cu} / \mathrm{L}$, respectively). All species tested were relatively insensitive to dissolved zinc up to concentrations of approximately $1,000 \mu \mathrm{g} / \mathrm{L}$. In addition and with the exception of $\mathrm{N}$. australiensis, all species accumulated significant levels of zinc in their body tissues. Whole-sediment tests were conducted over a 10-day period with copper-spiked $(1,300 \mu \mathrm{g} / \mathrm{g})$ and zinc-spiked $(4,000 \mu \mathrm{g} / \mathrm{g})$ sediments equilibrated for sufficient time to ensure that pore water metal concentrations were well below concentrations shown to have any effect on organisms in water-only tests. Survival was decreased in the bivalves T. deltoidalis and S. alba after exposure to copper-spiked sediments, and all species-except T. deltoidalis, in which $100 \%$ mortality was observed-accumulated copper in their tissues. Exposure to zinc-spiked sediments significantly decreased the survival of only one species, T. deltoidalis. Both polychaetes appeared to regulate concentrations of zinc in their body tissues with no significant uptake of zinc occurring from the sediment phase. Of the five species assessed in this study, T. deltoidalis was found to be the most sensitive to copper- and zinc-contaminated sediments, and based on commonly used selection criteria (ASTM 2002a, $2002 b, 2002 c$ ) is recommended for development as test species in whole-sediment toxicity tests.
\end{abstract}

\section{Keywords}

zinc, copper, accumulation, tests, toxicity, water, sediment, assessment, whole, bivalves, polychaetes, australian, five

\section{Disciplines}

Life Sciences | Physical Sciences and Mathematics | Social and Behavioral Sciences

\section{Publication Details}

King, C., Dowse, M., Simpson, S. L., Jolley, D. F. (2004). An assessment of five Australian Polychaetes and Bivalves for use in whole-sediment toxicity tests: toxicity and accumulation of Copper and Zinc from water and sediment. Archives of Environmental Contamination and Toxicology, 47 314-323. 
1 An assessment of five Australian polychaetes and bivalves for use in whole sediment toxicity tests:

2 toxicity and accumulation of copper and zinc from water and sediment.

3

$4 \quad$ C.K. King ${ }^{1}$, M.C. Dowse $^{1}$, S.L. Simpson ${ }^{1}$ and D.F. Jolley ${ }^{2}$

$5 \quad{ }^{1}$ Centre for Advanced Analytical Chemistry, CSIRO Energy Technology, Private Mailbag 7, Bangor, NSW

6 2234, Australia

$7{ }^{2}$ Oceans and Coastal Research Centre, Department of Chemistry, University of Wollongong, NSW 2522,

8 Australia

10 Corresponding author: C.K. King

11 Mailing address: Centre for Advanced Analytical Chemistry

12 CSIRO Energy Technology

13

Private Mailbag 7

14

Bangor, NSW 2234, Australia

15 Telephone: +61297106832

16 FAX: +61297106837

17

email: Catherine.King@csiro.au 
The suitability of two polychaete worms, Australonereis ehlersi and Nephtys australiensis and three bivalves, Mysella anomala, Tellina deltoidalis and Soletellina alba, were assessed for their potential use in whole-sediment toxicity tests. All species, except A. ehlersi, which could not be tested due to poor survival in water-only tests, survived in salinities ranging from 18 to $34 \%$ over the 96-h exposure period. No mortality was observed in any of the species exposed to sediment compositions ranging from $100 \%$ silt to $100 \%$ sand for 10-d, demonstrating the high tolerance of the five species to a wide range of sediment types. All species showed reduced survival following exposure to highly sulfidic sediments in 10-d whole-sediment tests. In 96-h water-only tests, survival decreased and copper accumulation in body tissues increased with exposure to increasing copper concentration for all species, except $A$. ehlersi, which again could not be tested due to its poor survival in the absence of sediment. Soletellina alba and T. deltoidalis were the most sensitive species to aqueous copper (LC50s of 120 and $150 \mu \mathrm{g} \mathrm{Cu} / \mathrm{L}$, respectively). All species tested were relatively insensitive to dissolved zinc up to concentrations of approximately $1000 \mu \mathrm{g} / \mathrm{L}$. In addition, with the exception of $N$. australiensis, all species accumulated significant levels of zinc in their body tissues. Whole sediment tests were conducted over $10 \mathrm{~d}$ with copper- $(1300 \mu \mathrm{g} / \mathrm{g})$ and zinc-spiked $(4000 \mu \mathrm{g} / \mathrm{g})$ sediments equilibrated for sufficient time to ensure pore water metal concentrations were well below concentrations shown to have any effect on organisms in water-only tests. Survival was reduced in the bivalves $T$. deltoidalis and $S$. alba following exposure to copper-spiked sediments, and all species, except $T$. deltoidalis in which $100 \%$ mortality was observed, accumulated copper in their tissues. Exposure to zincspiked sediments significantly reduced the survival of only one species, T. deltoidalis. Both polychaetes appeared to regulate concentrations of zinc in their body tissues, with no significant uptake of zinc occurring from the sediment phase. Of the five species assessed in this study, $T$. deltoidalis was found to be the most sensitive to copper- and zinc-contaminated sediments, and based on commonly used selection criteria (ASTM 2002a,b,c) is recommended for development as test species in whole sediment toxicity tests.

\section{Introduction}

Owing to the very limited information on the biological effects of contaminated sediments and the sensitivity of native Australian organisms to contaminants, the interim sediment quality guideline values (ISQG-low and ISQG-high "trigger value") adopted by Australia (ANZECC/ARMCANZ, 2000) are the effects rangelow (ERL) and -median (ERM) values, respectively, of Long et al. (1995). These empirical guidelines are threshold values based on total metal concentrations and no consideration is given to factors that modify sediment toxicity (e.g. AVS and organic carbon) (Ankley et al. 1996; Besser et al. 2003), the co-occurrence of other contaminants (e.g. metals and organics) that may confound the determination of effects 
Information on the sensitivity of benthic organisms to sediment contaminants is best obtained from toxicity tests on naturally- and artificially-contaminated sediments. While water exposure tests assess the tolerance of organisms to dissolved contaminants, whole-sediment toxicity tests expose organisms to contaminants bound to sediment particles and dissolved in pore water and overlying water (Ingersoll et al. 1997; ASTM 2002a,b,c; Batley et al. 2002). The accumulation and toxicity of metals from sediment and associated pore water by organisms are influenced by a number of physico-chemical (abiotic) and biological (biotic) parameters. Physico-chemical parameters include dissolved oxygen, temperature, $\mathrm{pH}$, hardness, salinity and organic components (Luoma 1990; Ingersoll et al. 1997; Chapman et al. 1998). An organism's feeding behaviour, respiration, mobility, and where and how it lives, are key biological factors affecting metal uptake and the toxicity of metal contaminated sediments (Luoma 1990; Langston and Spence 1995; Ingersoll et al. 1997).

Organisms used in sediment toxicity tests are intended to be generic representatives of species in the benthic community from which they are obtained (Ingersoll et al. 1997). As both the feeding and behaviour of an organism directly affect its exposure to contaminants within sediments, it is essential to select a range of organisms that have different routes of exposure to contaminants. Criteria used to select species for wholesediment toxicity tests include relative sensitivity to a range of contaminants, direct contact with the sediment and compatibility with exposure methods and endpoints, broad geographical distribution and high availability and abundance through either field collection or culture, ease of identification, tolerance to handling and ease of maintenance in the laboratory, and tolerance to varying sediment and water physicochemical characteristics (Ingersoll et al. 1997; ASTM 2002a,b,c).

21 Very few comprehensive protocols based on local species are available for routine sediment toxicity testing in Australia. This study assesses the suitability of five native sediment-dwelling marine invertebrates for use as test organisms in whole sediment toxicity tests. Two species of polychaete worms (Australonereis ehlersi, Nephtys australiensis) and three species of infaunal bivalves (Tellina deltoidalis, Soletellina alba, Mysella anomala) were investigated. All species are infaunal and inhabit a range of sediment types from fine mud to course sand, yet have different modes of feeding and living habits.

Australonereis ehlersi (Fam. Nereididae) is very common in estuarine and coastal areas throughout the southern region of Australia from Western Australia to Queensland. It forms a series of deep (up to $40 \mathrm{~cm}$ ), mucus-lined burrows in which it lives. It is predominantly a deposit feeder, ingesting sediment particles and detritus, although also has carnivorous attributes, with an eversible pharynx and a pair of jaws (Glasby et al. 2000). It grows to a length of $20 \mathrm{~cm}$, completes its life cycle within 1 to 1.5 years, and is thought to reproduce by epitoky and/or brooding of eggs in burrows (Glasby et al. 2000). Australia. This species grows to a length of $7 \mathrm{~cm}$ and burrows to a depth of at least $20 \mathrm{~cm}$. It is free living 
nephtyids in Australia have been undertaken. Like the majority of nephtyids, it is thought to feed primarily as a predator on small molluscs, crustaceans and other polychaetes. It may also feed on deposited sediments in the subsurface layer when prey items are scarce (Glasby et al. 2000). This species is likely to reproduce by broadcast spawning, external fertilisation of gametes and planktonic development of larvae in the water column (Glasby et al. 2000). Mysella anomala (Fam. Galeommatidae) is a common bivalve found in estuaries and coastal areas in New South Wales, Australia (Ponder 1998; Ponder et al. 2000). It grows to a length of approximately $20 \mathrm{~mm}$, and is a shallow burrower to depths of up to $10 \mathrm{~cm}$. The biology of this species has not been studied but it is thought to be free living. Like other members of this family, it feeds by filtering suspended particles from overlying waters and the larvae are brooded within the shell (Ponder 1998; Ponder et al. 2000).

11 Tellina deltoidalis (Fam. Tellinidae) is endemic to Australia and ranges from southern Queensland to 12 Tasmania and south Western Australia. It lives in estuarine and coastal lagoons, and grows to approximately $25 \mathrm{~mm}$ in length. The biology of this species has not been studied but like other tellinids, T. deltoidalis is presumably a deposit feeder, collecting organic material and particles from surface sediments. It is thought to reproduce by broadcast spawning with planktotrophic larvae (Willan 1998; Ponder et al. 2000). Soletellina alba (Fam. Psammobiidae) is endemic to Australia, inhabiting estuaries and sheltered bays from mid Queensland to South Australia. The thin and fragile shell of $S$. alba grows to a length of $50 \mathrm{~mm}$, and this species burrows up to depths of $300 \mathrm{~mm}$. The biology of this species has not been studied but it appears to filter feed on particulate matter, collected from the overlying water using its long inhalant siphon, which can protrude well above the surface of the sediment (King, pers. obs.). It may also deposit feed on sediments and detritus, and probably reproduces by broadcast spawning with planktotrophic larvae (Ponder 1998; Willan 1998; Ponder et al. 2000). In this study, survival of organisms and bioaccumulation of copper and zinc following 96-h water-only and 10-day spiked-sediment exposures were investigated. Recommendations are made on the suitability of these organisms as test species, and on the additional studies required to better develop these species for use in whole sediment toxicity testing.

\section{Materials and Methods}

\section{Test media}

30 Clean seawater was collected from Port Hacking, Sydney, Australia, membrane filtered $(0.45 \mu \mathrm{m})$, and 31 acclimated to the room temperature of $21 \pm 1^{\circ} \mathrm{C}$. Where necessary, the salinity of the filtered seawater was 32 adjusted to the test salinity of 30\%o using Milli-Q deionised water (18 M $\Omega$; Milli-Q Academic Water 33 System). 
Control (uncontaminated) sediment from Bonnet Bay, Woronora River, Australia was collected from the surface layer (top 2-4 cm) using a clean stainless steel shovel and was sieved on site $(1.1 \mathrm{~mm})$. The physicochemical properties of the sediment are typical of the silty sediments found at sites in the upper reaches of estuaries on the south east coast of Australia. The sediment was a hydrous (68\% water) silty sediment (99\% particles $<63 \mu \mathrm{m})$, and was sub-oxic $(<0.5 \mu \mathrm{mol} / \mathrm{g}$ acid-volatile sulfide, the salinity and $\mathrm{pH}$ of pore water were $29 \%$ and 7.3 , respectively. The sediment had $12 \pm 2 \%$ organic carbon and acid-extractable (30 min, 1 $\mathrm{M} \mathrm{HCl}$ ) metal concentrations (in $\mu \mathrm{g} / \mathrm{g}$ ) of $6000(\mathrm{Fe}), 50(\mathrm{Mn}), 160(\mathrm{Zn}), 66(\mathrm{~Pb}), 30(\mathrm{Cu}), 4.1(\mathrm{Ni})$ and 1.0 (Cd) (Simpson et al. 2004). Pore water concentrations of sulfide, iron and manganese were $<50,7000 \pm 4000$ and $700 \pm 300 \mu \mathrm{g} / \mathrm{L}$, respectively, and other trace metals were $<3 \mu \mathrm{g} / \mathrm{L}$. Concentrations of total polycyclic aromatic hydrocarbons (13 PAHs, ANZECC/ARMCANZ, 2000) in the sediments were $<2 \mathrm{mg} / \mathrm{kg}$ (normalised to $1 \%$ organic carbon). Concentrations of other organics (e.g. pesticides, PCBs) were below analytical detection limits.

Clean Sydney Sand was purchased locally and used in particle size tests and for depuration of A. ehlersi at the termination of tests, as this species does not survive in water only conditions.

\section{Collection and handling of test organisms}

Organisms were collected during low tide from sand and mud flats between March and October 2001 at locations in Sydney, Australia. Collection locations included Boronia Park, Lane Cove River (A. ehlersi, N. australiensis, T. deltoidalis, S. alba), Sailors Bay, Middle Harbour (A. ehlersi, N. australiensis, S. alba, M. anomala), and Prince Edward Park, Woronora River (A. ehlersi, S. alba). The lengths of organisms collected and used in this study were 40-50 mm (A. ehlersi and N. australiensis), 4-5 mm (M. anomala), and 15-20 mm (T. deltoidalis and S. alba).

Sediment from a maximum depth of $20 \mathrm{~cm}$ was gently sieved through a $1.1 \mathrm{~mm}$ mesh, and the animals retained on the mesh were sorted by species and counted into polyethylene containers (Décor, 12x18x10) filled with sieved sediment to a depth of $8 \mathrm{~cm}$ and overlying water from the collection site. Containers holding animals were capped, kept cool in ice chests and transported to the laboratory with minimal disturbance.

In the laboratory, containers holding test organisms were submerged in plastic trays $(30 \times 50 \mathrm{~cm})$ and covered with filtered seawater at the same salinity as the collection site. The overlying water in trays was aerated and monitored daily to ensure appropriate salinity, dissolved oxygen levels and water circulation were maintained. Prior to experiments, organisms were acclimated to laboratory test conditions (temperature of $21^{\circ} \mathrm{C}$ and salinity of $34 \%$ ) for 2 to $7 \mathrm{~d}$ in their holding trays. Organisms were sieved (500 or $1000 \mu \mathrm{m} \mathrm{mesh}$ ) from holding trays and placed in a shallow tray of filtered seawater to remove excess sediment before being added to test beakers. Organisms were fed Sera micron fry food ( $1 \mathrm{mg} /$ organism) every 3 days and were used for tests within 7 days of collection from the field. 


\section{General analytical}

All glass and plasticware for analyses was cleaned by soaking in $10 \%(\mathrm{v} / \mathrm{v}) \mathrm{HNO}_{3}(\mathrm{BDH}$, Analytical Reagent grade) for a minimum of $24 \mathrm{~h}$ followed by thorough rinsing with Milli-Q water. Glass beakers and acrylic beaker-lids used for toxicity tests were cleaned in a dishwasher (Gallay Scientific Pty Ltd) programmed for a phosphate-free detergent wash (Clean A, Gallay Scientific Pty Ltd), a dilute acid wash $\left(1 \% \mathrm{HNO}_{3}\right)$, followed by thorough rinsing with Milli-Q water.

Measurements of $\mathrm{pH}$ (calibrated against National Institute of Standards and Technology (NIST) buffers) and redox potential (versus the standard hydrogen electrode) were done using $\mathrm{pH}$ or redox probes as described previously (Simpson and Batley 2003). Salinity, temperature and dissolved oxygen measurements were made in accordance with the instrument manufacturer's instructions. Sediment pore water was extracted by centrifugation ( $5 \mathrm{~min}, 2500 \mathrm{rpm}, 18-22^{\circ} \mathrm{C}$ ) under a nitrogen atmosphere (Simpson et al. 2002). Pore water and overlying water samples were membrane filtered $(0.45 \mu \mathrm{m})$ immediately following collection and acidified with concentrated $\mathrm{HNO}_{3}\left(2 \% \mathrm{HNO}_{3}(\mathrm{v} / \mathrm{v})\right.$, Tracepure, Merck). Methods for analyses of sediment particle size (wet sieving) and organic carbon (loss on ignition, $450^{\circ} \mathrm{C}$ ), total (aqua regia) and acidextractable (1-M HCl, 30 min) metals analyses have been described previously (Simpson et al. 2002).

\section{Test apparatus}

All experiments were conducted in 1-L glass beakers. Test beakers were kept at a temperature of $20 \pm 1^{\circ} \mathrm{C}$ in

Dissolved metal concentrations in water samples and digested sediments were determined by inductively coupled plasma atomic emission spectrometry (ICP-AES, Spectroflame EOP, Spectro Analytical Instruments) calibrated with matrix-matched standards. Acid-volatile sulfide was analysed according to Simpson (2001).

$$
\text { an environmental chamber (Labec Refrigerated Cycling Incubator) on a } 12 \mathrm{~h} \text { light/ } 12 \mathrm{~h} \text { dark cycle (light }
$$
intensity $=3.5 \mu \mathrm{mol}$ photons $/ \mathrm{s} / \mathrm{m}^{2}$ ) for the duration of the test. These conditions are representative of average environmental conditions in estuaries in Sydney, Australia. Beakers were bubbled with air to maintain dissolved oxygen levels at $85-100 \%$ saturation. A salinity of $30 \pm 1 \%$ (except for the salinity test), and a $\mathrm{pH}$ of $8.0 \pm 0.2$ in waters were maintained throughout the tests. Water quality parameters including salinity, temperature, $\mathrm{pH}$ and dissolved oxygen were monitored at the start and termination of each test. Test beakers were monitored daily to ensure there was adequate aeration and minimal evaporation.

Water-only tests were conducted for $96-\mathrm{h}$ in beakers containing $900 \mathrm{~mL}$ of test water. Whole sediment tests were conducted for 10 days in beakers containing $200 \mathrm{~g}$ of sediment and filled to $900 \mathrm{~mL}$ with overlying filtered seawater. A total of 10 individuals (for A. ehlersi, N. australiensis and S. alba) or 15 individuals (for $M$. anomala and $T$. deltoidalis) were randomly assigned to each test beaker. This corresponds to an organism-loading rate in test beakers of 3.7, 0.8, 4.4, 0.3 and $1.4 \mathrm{~g}$ wet weight/L for each of the species respectively. While for three of the test species this is higher than the recommended load of $0.8 \mathrm{~g} / \mathrm{L}$ for 
aqueous tests (ASTM 1996), beakers were bubbled with air so that dissolved oxygen levels did not fall below $90 \%$ saturation. In addition, these densities are similar to those observed in the field at collection sites and hence organisms were not overcrowded and did not appear to be stressed. For each experiment, 4 replicate beakers were used per treatment, except for the particle size and salinity tolerance tests with Nephtys australiensis, in which 2 replicate beakers only were used, due to insufficient numbers of animals.

\section{Tolerance to environmental factors}

The tolerance of organisms to the physical parameters tested was determined as the percent survival of organisms at the termination of tests. The tolerance to salinities ranging from 0 to $34 \%$ was investigated in water-only tests. Each salinity treatment was prepared by adding Milli-Q water to filtered seawater to achieve the desired salinity and was checked with a salinity meter. The tolerance of organisms to sediments with different particle size ranges was tested using 10-day whole sediment tests with particle size compositions ranging from $100 \%$ silt $(<63 \mu \mathrm{m})$ to $100 \%$ sand $(0.5-1 \mathrm{~mm})$ in $25 \%$ increments. These treatments were prepared from mixtures of clean sand (100\% Sydney sand) and control sediment from the Woronora River (100\% silt). The tolerance of organisms to anoxic, sulfide-rich sediments was assessed in 10-day whole sediment tests. Control sediment from Woronora River was spiked with sufficient dissolved sulfide $\left(\mathrm{Na}_{2} \mathrm{~S}\right)$ to convert all reactive $\mathrm{Fe}$ and $\mathrm{Mn}$ to sulfide phases (e.g. FeS). The sulfide-spiked sediments were allowed to equilibrate for 48-h (mixing twice daily), then the excess pore water sulfide was removed by centrifuging and fresh seawater added to obtain the originals water content (68\%). The acid-volatile sulfide content of the prepared sediment was in the range of 300 to $400 \mu \mathrm{mol} / \mathrm{g}$. Pore water sulfide concentrations in these sediments were $200-1000 \mu \mathrm{g} / \mathrm{L}$.

\section{Tolerance to copper and zinc contaminated waters and sediments}

For 96-h water-only exposures to dissolved copper and zinc, nominal metal concentrations $(0-4000 \mu \mathrm{g} / \mathrm{L})$ were prepared by addition of dissolved copper $\left(200 \mathrm{mg} / \mathrm{L} \mathrm{CuSO} \mathrm{CH}_{4} .5 \mathrm{H}_{2} \mathrm{O}\right.$ stock, $\left.0.05 \% \mathrm{HCl}\right)$ or zinc $(500 \mathrm{mg} / \mathrm{L}$ $\mathrm{ZnSO}_{4} .7 \mathrm{H}_{2} \mathrm{O}$ stock, $0.05 \% \mathrm{HCl}$ ) to test beakers. A control and up to 5 treatments (metal concentrations) were tested in each experiment. Water samples were taken from test beakers for metal analysis at the start and termination of tests.

The 10-d sediment exposures were performed with control sediment from Woronora River spiked with copper and zinc. Measured concentrations in the control sediment were $<50 \mu \mathrm{g} \mathrm{Cu}$ and $<240 \mu \mathrm{g} \mathrm{Zn/g} \mathrm{dry}$ weight sediment. Nominal total metal concentrations in metal-spiked sediments were 1300 and $4000 \mu \mathrm{g} / \mathrm{g}$

30 dry weight sediment, respectively. These concentrations were 20 times the Australian guideline ISQG-low

31 values (trigger values) for these metals in marine sediments $(65 \mu \mathrm{g} \mathrm{Cu} / \mathrm{g}$ and $200 \mu \mathrm{g} \mathrm{Zn} / \mathrm{g}$ )

32 (ANZECC/ARMCANZ 2000). At the start and termination of each whole-sediment test, the overlying water, pore water and whole sediment were sampled for metal analysis. 
Metal-spiked sediments were prepared in a nitrogen-filled glove box by the addition of $700 \mathrm{~mL}$ of metalstock solution to $1200 \mathrm{~g}$ of wet control sediment in a 2-L bottle (Nalgene). The metal stock solution was prepared by dissolving the appropriate amount of metal solid $\left(\mathrm{CuSO}_{4} .5 \mathrm{H}_{2} \mathrm{O}\right.$ or $\left.\mathrm{ZnSO}_{4} \cdot 7 \mathrm{H}_{2} \mathrm{O}\right)$ in deoxygenated filtered seawater. Immediately prior to the addition to the sediments, sufficient $\mathrm{NaOH}(15 \mathrm{M})$ was added to stock solutions to bring the final $\mathrm{pH}$ of spiked sediments to approximately 8 (determined in preliminary experiments). This $\mathrm{pH}$ was chosen to promote the partitioning of metals to sediment particles, ensure that the majority of iron(II) displaced to the pore waters by the added metals would oxidise and precipitate as iron hydroxide phases and minimise fluxes to the overlying water (Simpson et al. 2004). During mixing, the water content (weight $\%$ ) of the metal-spiked sediments was $80 \%$, while that of the original control sediment was $68 \%$. The $\mathrm{pH}$-adjusted metal-spiked sediments were capped, rapidly shaken for $30 \mathrm{~s}$ then rolled on a bottle roller for $4 \mathrm{~h}$ before returning to the nitrogen glove box. The spiked sediments were equilibrated for a minimum of 14 days. During this time, sediments were mixed (by rolling) every $1-2 \mathrm{~d}$ for a minimum of $2 \mathrm{~h}$ and were maintained at $\mathrm{pH} 8$ by small additions of $\mathrm{NaOH}$. Pore waters were sampled every few days to monitor dissolved metal concentrations. Following this equilibration period, spiked sediments were returned to the original water content $(68 \%)$ by removing the bulk of the pore water by centrifugation and then adding fresh filtered seawater. The $\mathrm{pH}$ and redox potential of sediments were determined at the start and termination of tests.

\section{Metal concentrations in animals}

At the termination of tests, surviving animals were counted and were allowed to depurate overnight in clean filtered seawater (with sand for A. ehlersi as this species does not survive in water-only conditions). Whole specimens of the polychaetes A. ehlersi and N. australiensis, and of the bivalve M. anomala (due to its small size and difficulty in removing the shell to obtain soft tissue only), or the soft tissues only after removal of the shell of the two larger bivalves, $T$. deltoidalis and S. alba, were used to obtain wet and dry weights and for the analysis of metals in organisms. These were placed in pre-weighed $10 \mathrm{~mL}$ polycarbonate vials $(1$ animal/vial) and were dried at $60^{\circ} \mathrm{C}$ for a minimum of $12 \mathrm{~h}$. After cooling at room temperature in a desiccator, each vial was reweighed to calculate the dry weight (DW) of the animal. Ultra pure $\mathrm{HNO}_{3}($ Trace Pur Merck, $0.5 \mathrm{~mL} / 0.1 \mathrm{~g} \mathrm{DW}$ ) was added to each vial, which was capped and left at room temperature for $24 \mathrm{~h}$ to digest. Vials were then heated (20/batch) in a domestic microwave oven for $20 \mathrm{~min}(1100 \mathrm{~W}$; $10 \%$ power). After cooling at room temperature, $\mathrm{H}_{2} \mathrm{O}_{2}(30 \%$, AR grade) was added to each vial $(0.5 \mathrm{~mL} / 0.1 \mathrm{~g}$ DW), and vials were left for $24 \mathrm{~h}$ to further digest. Vials were microwaved (as above) and allowed to cool to room temperature. Samples were diluted with Milli-Q water to a final volume of $10 \mathrm{~mL} / 0.1 \mathrm{~g} \mathrm{DW}$. Metal concentrations were measured by ICP-AES. For quality control purposes, each batch of samples analysed included one blank (Milli-Q water) and two reference samples (TORT-2, National Research Council Canada). 
2 Survival data was arcsine transformed and Analysis of Variance (ANOVA) was used to test for differences in the proportion of live organisms between treatments and between species for each of the physical parameters tested (salinity, particle size, sediment type) and in metal-spiked sediment tests. StudentNewman-Keuls (SNK) tests were used following ANOVA to compare means. All ANOVA and SNK tests were done using the software GMAV5 (Analysis of Variance Package, A.J. Underwood and G.M. Chapman, Institute of Marine Ecology, University of Sydney, Australia).

Maximum Likelihood Regression using Probit Analysis with Abbott's correction was used to determine point estimates including LC50 values and 95\% confidence limits (CL) for $\mathrm{Cu}$ and $\mathrm{Zn}$ water exposure tests. NOEC and LOEC values were determined by comparing multiple treatments with a single control using Dunnett's multiple comparison test (parametric) or Steel's Many-One Rank test (non-parametric). All point estimate and hypothesis testing procedures were done using the software Toxcalc (V5) for Microsoft Excel (Tidepool Scientific Software, California, U.S.A.).

\section{Results and Discussion}

\section{Tolerance to environmental factors}

Tolerance to key physical factors including salinity, sediment particle size and oxygen conditions within sediments were used to determine the suitability of species for testing a range of different sediment types and environmental conditions, and to establish optimum conditions for toxicity tests. As A. ehlersi could not survive in water-only exposures, the effect of salinity on this species was not tested. All other species were able to tolerate a range of salinities, $N$. australiensis (5-34\%o), S. alba (5-34\%o), T. deltoidalis (10-34\%o) and M. anomala (18-34\%o) as shown in Figure 1. All species were found to have a high tolerance ( $>98 \%$ survival) to the full range of sediment particle sizes tested (100\% silt to $100 \%$ sand). These results are in agreement with the wide distribution of the species in estuarine and coastal systems of southern Australia, where the species inhabit waterways of varying salinities and in a variety of habitats from muddy sediments through to coarse sands (Ponder 1998; Willan 1998; Glasby et al. 2000; Ponder et al. 2000). Even at the collection sites, they are exposed to a wide range of salinities on a daily basis as a result of tidal fluctuations (e.g. Boronia Park, 19 to $28 \%$ ).

Survival of test organisms was significantly reduced following exposure to highly sulfidic sediments ( $>300$ $\mu \mathrm{mol} / \mathrm{g}$ AVS; $P<0.05)$. For N. australiensis, T. deltoidalis and S. alba, $100 \%$ mortality was observed following exposure to sulfidic sediment conditions. Survival of A. ehlersi was reduced to $54 \%$ of control, and survival of $M$. anomala was reduced to $81 \%$ of control. The reduced impact of sulfidic sediments on $M$. 
burrower (Ponder 1998; Ponder et al. 2000) and its contact with the sulfide-rich sediments below the bioturbated surface layer may have been limited. The polychaete worm, A. ehlersi, constructs tubes that they irrigate and oxygenate with overlying water, thus limiting their contact with the sulfidic sediment. Vismann (1990) and Miron and Kristensen (1993a) found that the polychaetes Nereis diversicolor and N. succinea have high sulfide detoxification capacities within body tissues, which allows them to survive in sulfide-rich environments. Miron and Kristensen (1993b) further investigated the tolerance of $N$. diversicolor, $N$. virens and $N$. succinea to sulfide, through the injection of sulfide into burrows over a period of 3 hours. Two of the species were found to remove sulfide from burrows at a rate that would allow colonisation to occur in sulfidic habitats. This may also be the case for the test species A. ehlersi.

\section{Sensitivity to aqueous copper and zinc}

11 During water-only tests, $\mathrm{pH}$ ranged from 8.01 to 8.20 , temperature ranged from 20.2 to $21.3^{\circ} \mathrm{C}$, DO was $>95 \%$ saturation, and salinity ranged from 30 to $31 \%$. At the start of tests, measured copper and zinc concentrations were within 5-15\% of the nominal test concentrations. Over the duration of the 96-h tests however, dissolved metal concentrations decreased on average by $50 \%$ (copper) and $30 \%$ (zinc). This was attributed both to metal accumulation by the test organisms and to loss to glass beaker walls. When toxicant concentrations decrease over the test duration, the effects concentrations (e.g. LC50s) will be over-estimated if initial concentrations only are used in calculations (Simpson et al. 2003). Because the decline in 'toxicant' concentration was significant during the test period, especially for copper, both the initial and the mean of the initial and final measured dissolved metal concentrations were used to calculate the effect concentrations (Tables 1 and 2). Effects concentrations based on mean values were considerably lower than those calculated from initial concentrations only. For example, LC50 values for copper and zinc in S. alba calculated using mean dissolved metal concentrations were approximately $40 \%$ lower than LC50 values calculated using initial concentrations. In addition, for tests where water concentrations decrease at a faster rate during the early stages of the exposure period than for the final stages, using the mean of initial and final concentrations may still overestimate the effect concentrations. Using mean concentrations is, however, much more appropriate than using nominal or initially measured water concentrations only (Simpson et al. 2003).

For all species (excluding A. ehlersi, which was not tested due to its inability to survive in water-only exposures), survival of organisms was $>95 \%$ in the control filtered seawater and was reduced following exposure to increasing concentrations of dissolved copper (Figure 2a). The effects concentrations calculated using the initial and mean (of initial and final) dissolved copper concentrations, are shown in Table 1. Mysella anomala was the least sensitive species, with an LC50 value (mean data) ten times greater than that of the other species $(1500 \mu \mathrm{g} / \mathrm{L}$, Table 1$)$. This is similar to the sensitivity reported for the bivalve Scrobicularia plana (Bryan 1976). In contrast, the bivalves S. alba and T. deltoidalis were the most sensitive species to aqueous copper (mean LC50 $=120 \mu \mathrm{g} / \mathrm{L}$ and $150 \mu \mathrm{g} / \mathrm{L}$ respectively, Table 1 ). The polychaete 
worm, $N$. australiensis, had an LC50 value of $210 \mu \mathrm{g} / \mathrm{L}$ for copper and was similar in sensitivity to polychaete species reported elsewhere, including Neanthes arenaceodentata (LC50 =300 $\mu \mathrm{g} / \mathrm{L}$; Reish et al. 1976) and Nephthys hombergi $(\mathrm{LC} 50=250 \mu \mathrm{g} / \mathrm{L} ;$ Bryan 1976).

Zinc was much less toxic to all test species than copper in water only exposures (Tables 1 and 2). The effect concentrations calculated for the dissolved zinc exposures are shown in Table 2. Not all species had graded responses to exposure to increasing dissolved zinc concentrations, unlike exposure to copper. For $N$. australiensis and T. deltoidalis, no effect on survival was observed in dissolved zinc concentrations up to 5900 and $7900 \mu \mathrm{g} / \mathrm{L}$, respectively (initial data, Table 2). While survival of the bivalves, $M$. anomala and $S$. $a l b a$, decreased significantly as zinc concentrations increased above $1000 \mu \mathrm{g} / \mathrm{L}$ (Figure 2b), these species were also quite insensitive to zinc (LC50 values of 4400 and $4900 \mu \mathrm{g} / \mathrm{L}$, respectively, Table 2).

\section{Sensitivity to sediment-bound copper and zinc}

12 During whole-sediment tests, the metal-spiked sediments had $\mathrm{pH}$ of 7.80-8.05 and redox potential of 0-100 $\mathrm{mV}$. The $\mathrm{pH}$ of overlying water ranged from 7.80 to 8.20 , DO was $>90 \%$ saturation, temperature ranged from 20.4 to $21.8^{\circ} \mathrm{C}$ and salinity ranged from 30 to $31 \%$. The total metal concentrations in the metal-spiked sediments, pore waters and overlying waters at the start and termination of the tests are shown in Table 3. For all metal-spiked sediments, there was a release of metal from the sediments to the overlying waters over the 10-d test period. The magnitude of this release did not appear to be dependent on the species of organism under investigation (Table 3). Pore water metal concentrations generally decreased during the test period, however the differences between initial and final pore water concentrations were not as great as those observed for overlying waters (Table 3). Previous studies have also shown that the addition of organisms to sediments disturbs pore water metal concentrations, producing fluxes to the overlying water, and it may take several weeks to re-establish equilibrium (Riedel et al. 1997; Simpson and Batley 2002).

High zinc and copper concentrations were observed in the pore waters (up to $91 \mu \mathrm{g} \mathrm{Cu} / \mathrm{L}$ and up to $780 \mu \mathrm{g}$ $\mathrm{Zn} / \mathrm{L}$ and $)$ and overlying waters ( $140 \mu \mathrm{g} \mathrm{Cu} / \mathrm{L}$ and $470 \mu \mathrm{g} \mathrm{Zn/L)} \mathrm{during} \mathrm{the} \mathrm{tests.} \mathrm{The} \mathrm{average} \mathrm{Zn}$ concentrations (mean of initial and final data) in the pore water and overlying waters in tests were however, at least 4 times less than the lowest concentration observed to cause effects (LOEC) in the 96-h water only exposures. Similarly for $\mathrm{Cu}$, average concentrations in the pore water and overlying waters (mean of initial and final data) were less than the LOEC values for all species.

For all test species, survival in the control sediment was high (>95\%). Exposure to zinc-spiked sediments had no significant effect on the survival of four of the test species as compared to the controls $(P>0.05$; Figure 3). Survival following exposure to zinc-spiked sediment, however, was reduced relative to the control for $T$. deltoidalis $(88 \% ; P<0.01)$. Whether this small reduction in survival represents an ecologically relevant effect is questionable however. Exposure to copper-spiked sediments had no effect on the 
13 ). In contrast, survival of the bivalves $T$. deltoidalis and S. alba in copper-spiked sediments was reduced

2 significantly $(P<0.01)$ relative to the controls. For $T$. deltoidalis, $100 \%$ mortality was observed in copperspiked sediments, while for S. alba, survival was reduced to $23 \%$ of control. As mentioned above, copper concentrations in the pore water and overlying water were elevated during these tests. It is therefore possible that for S. alba and T. deltoidalis, the overlying water copper concentrations (Table 3) were sufficient to cause some of the observed mortalities (96-h LC50s, Table 1). Sediment-bound copper may also have an important contribution to the high mortality of T. deltoidalis.

\section{Accumulation of metals from waters and sediments}

The average dry weights of the soft tissues of organisms used in tests were $55 \mathrm{mg}$ (A. ehlersi), $15 \mathrm{mg}(N$. australiensis), $14 \mathrm{mg}$ (T. deltoidalis) and $59 \mathrm{mg}$ (S. alba). The average dry weight of whole organisms of M. anomala (including shell and soft tissue) was $9 \mathrm{mg}$. Concentrations of copper or zinc in body tissues of test organisms increased as the concentration of dissolved metals increased in water-only tests, with the exception of $N$. australiensis exposed to zinc (Figures 4a, b). All species (except $T$. deltoidalis in which $100 \%$ mortality occurred and no animals were available for measurements) also accumulated copper in their tissues following exposure to copper-spiked sediments, and concentrations of copper in animals exposed to copper-spiked sediments were significantly higher than the controls $(P<0.05$ or $P<0.01$; Figure 5a). Concentrations of zinc in body tissues of all three bivalves were also significantly higher in animals exposed to zinc-spiked sediment than in those exposed to control sediments $(P<0.01$; Figure $5 b)$. Mysella anomala however, only accumulated marginal amounts of either copper or zinc from sediments relative to the other species, while $S$. alba accumulated the greatest amounts (Figures $5 \mathrm{a}, \mathrm{b}$ ). In contrast, for both polychaetes, there was no significant accumulation of zinc from zinc-spiked sediments as compared to the control sediment $(P>0.05$; Figure $5 b)$. The use of sand in the depuration process for A. ehlersi may have increased the removal rate of ingested sediments through the gut and may have attributed to the lack of accumulation of zinc from zinc-spiked sediments in this species.

As zinc was not assimilated into the tissues of either of the polychaetes following water and/or sediment exposure, it is possible that these worms are able to regulate zinc assimilation from their environment. This regulation may enable these species to tolerate high concentrations of zinc in their environment, as indicated by their relative insensitivity to either aqueous or sediment-bound zinc (Figures 2b, 3). Regulation of zinc in body tissues has been reported in other Nereid polychaetes (e.g. Nereis diversicolor; Bryan and Hummerstone 1973). In addition, a zinc-tolerant population of $N$. diversicolor had reduced uptake of zinc in comparison to polychaetes from a non-contaminated site (Rainbow 1990). While zinc tissue concentrations did not increase in A. ehlersi when exposed to zinc-spiked sediments, concentrations of zinc in animals exposed to copper-spiked sediments did decrease relative to the controls (data not shown). This further suggests that A. ehlersi may regulate zinc with concentrations decreasing in body tissues when organisms are 
1 In contrast to zinc, both polychaetes accumulated copper following exposure to copper-spiked sediments.

2 Sediment is likely to be a major route of exposure to some contaminants through sediment ingestion in these species. This is especially true for A. ehlersi as it feeds directly on deposited sediments. Previous studies have shown that other Nereids that feed predominantly on sediments can accumulate high levels of copper in body tissues via this route (Glasby et al. 2000). Aqueous copper was also taken up by $N$. australiensis, with tissue concentrations of approximately $450 \mu \mathrm{g} / \mathrm{g} \mathrm{DW}$ in worms following 96-h exposure to $320 \mu \mathrm{g} \mathrm{Cu} / \mathrm{L}$ (Figure 4a). Accumulation in sediment tests in comparison was up to $200 \mu \mathrm{g} / \mathrm{g}$ DW following $10-\mathrm{d}$ exposure to $1400 \mu \mathrm{g} \mathrm{Cu} / \mathrm{g}$ in sediment and $<95 \mu \mathrm{g} \mathrm{Cu} / \mathrm{L}$ in overlying and pore water (Figure $5 \mathrm{a}$ ). In comparison to the accumulation of metals observed in water-only tests with $N$. australiensis, accumulation was higher in the sediment exposures than would be expected from the concentration of copper and zinc in the porewater alone. While some accumulation of metals in this species can clearly be attributed to uptake from the sediment/particulate phase, interpretation of the relative contribution of the water and sediment routes of uptake in this species (and in the other species) is difficult as background concentrations of metals in organisms varied between water and sediment tests.

Although significant mortality of $M$. anomala was only observed at extremely high concentrations of both copper and zinc in water only tests, copper and zinc accumulated in the body tissues of $M$. anomala in both water-only and sediment tests. Following 96-h aqueous exposure, copper (Figure 4a) and zinc (Figure 4b) concentrations in body tissues of this species accumulated to 5-6 times the concentrations in control organisms, tripling in body tissue concentrations as test concentrations doubled. For this species, only slightly higher accumulation in the sediment exposures occurred than would be expected due to uptake of copper and zinc from the porewater alone. This result and the high copper and zinc concentrations in $M$. anomala in water-only tests indicate that the dissolved phase is an important exposure pathway to metals. These findings are consistent with the living habits of $M$. anomala and its filter-feeding behaviour (Ponder 1998; Ponder et al. 2000).

In water-only tests, $T$. deltoidalis accumulated high levels of copper (up to $380 \mu \mathrm{g} / \mathrm{g} \mathrm{DW}$ ) in its tissues following exposure to $190 \mu \mathrm{g} / \mathrm{L}$ (Figure $4 \mathrm{a}$ ). At water concentrations greater than $190 \mu \mathrm{g} / \mathrm{L}$, most organisms died during the 96-h exposure period (Figure 2a), and hence tissue concentrations could not be measured. Zinc water-only tests with $T$. deltoidalis showed no mortality for exposures up to $6 \mathrm{mg} \mathrm{Zn/L}$, and tissue zinc concentrations increased significantly with increasing aqueous concentration, tripling as concentrations doubled (Figure $4 \mathrm{~b}$ ). The ability of $T$. deltoidalis to accumulate large amounts of zinc demonstrates a high zinc tolerance compared with other test species. This tolerance could be due to the organism's ability to immobilise assimilated zinc through sequestering and storage of the metal into cysteine-rich metallothionein proteins. In addition, $T$. deltoidalis may be able to metabolically detoxify dissolved $\mathrm{Zn}$ species within the 
1 In the whole-sediment toxicity tests, T. deltoidalis was the most sensitive to sediment-bound zinc (Figure 3),

2 and accumulated very little $\mathrm{Zn}$ from the sediment phase (Figure 5b). For copper tests, $100 \%$ mortality of $T$.

3 deltoidalis occurred following exposure to $1300 \mu \mathrm{g} \mathrm{Cu} / \mathrm{g}$ in sediments, so accumulation data was not

4 obtained in tests with copper-spiked sediments. Concentrations in the body tissues of T. deltoidalis only increased slightly with exposure to increasing aqueous copper concentrations. These results, along with the fact that all organisms died in copper-spiked sediments, indicate that both sediments and water are likely to be important exposure routes of contaminant uptake in this species. Studies of metal uptake pathways in $T$. deltoidalis using radiotracers have indicated that this species accumulates metals predominantly via filterfeeding, hence contaminants in overlying waters would have a significant impact on $T$. deltoidalis response (King et al. in prep).

11 Accumulation of copper via water exposure occurred in $S$. alba but was lower at the limit of its tolerance range than that in other species at their tolerance range limits. In the copper-spiked sediments, however, the uptake of copper by S. alba was generally greater than in other species. Accumulation of zinc in water and sediment tests reached concentrations of approximately 800 and $900 \mu \mathrm{g} / \mathrm{g} \mathrm{DW}$, respectively, indicating that S. alba can accumulate zinc through both water and sediments. For both $\mathrm{Cu}$ and $\mathrm{Zn}$, accumulation was higher following sediment exposure than would be expected from the concentration of copper and zinc in the porewater alone, hence accumulation of metals in this species can be attributed to uptake from both the aqueous and sediment phases.

The survival and accumulation of copper and zinc in tissues of organisms in water and sediment tests was largely dependent upon the feeding and living habits of each species. Overall, T. deltoidalis and S. alba were the most sensitive to copper in water and sediment tests, and showed some sensitivity to zinc-spiked sediments. Both aqueous and sediment bound metals were found to contribute to the accumulation of metals in all test species. To better determine the relative contribution of these different routes of exposure to uptake in these organisms, specific tests to determine accumulation at similar water-only and pore-water concentrations and using organisms with similar background concentrations in tissues would have to be done.

\section{Chemical properties and toxic effects of metal-spiked sediments}

Many recent studies have highlighted the importance of considering both aqueous and dietary pathways for contaminant uptake and effects (Wang and Fisher 1999; Wang 2002). An important consideration of the current study was to investigate the sensitivity of benthic organisms to both dissolved and sediment-bound contaminants.

To test the tolerance of the invertebrate species to copper and zinc-contaminated sediments, it was desirable to use sediments containing copper or zinc that were free of other contaminants. The only copper- and zinccontaminated sediments available from field locations were unsuitable for use in this study because they 
contained a suite of other contaminants. Artificially-contaminated (spiked) sediments should attempt to mimic naturally contaminated sediments that might be collected from the field. However, it is difficult to add large quantities of metals to sediments without causing major disruptions to sediment pore water $\mathrm{pH}$ and redox potential, displacing large quantities of weakly bound metals (e.g. Fe(II)) and causing the precipitation of large amounts of metals (e.g. $\left.\mathrm{Fe}(\mathrm{OH})_{3(\mathrm{~s})}, \mathrm{Cu}(\mathrm{OH})_{2(\mathrm{~s})}\right)$ (Simpson et al. 2004). The metal-spiked sediments equilibrated slowly and after 14 days, pore water metal concentrations appeared to be stabilising at low concentrations. In the metal-spiked sediments, pore water iron concentrations were 100-500 $\mu \mathrm{g} / \mathrm{L}$ compared to $7000 \pm 4000 \mu \mathrm{g} / \mathrm{L}$ in the original sediment.

Sediment properties strongly influence the equilibration rate for metals added to sediments, and for sediments with a low density of binding sites, pore water equilibration time may be much longer (Simpson et al. 2004). Consequently, the results from the whole-sediment toxicity tests with the metal-spiked sediments may have been significantly different had the control sediments had different properties. The influence of metal-spiking on food sources in sediments is poorly understood, however it is likely that additions of large quantities of metals greatly affect bacterial and algal populations. Metal-spiked sediments are expected to represent a worst-case scenario for bioavailable sediment-bound metals due to the much shorter equilibration times compared to sediments with high concentrations of contaminants that have accumulated over many years.

\section{Recommendations for sediment toxicity assessments in Australia}

The five invertebrates investigated in this study met many of the criteria used for selecting test organisms (Ingersoll et al. 1997; ASTM 2002a,b,c). All species live in direct contact with the sediment and are tolerant to a wide range of sediment and water physico-chemical characteristics. All species are available and abundant year round from field collections, are ecologically relevant, and have a wide distribution (Ponder 1998; Willan, 1998; Glasby et al. 2000; Ponder et al. 2000). All species were easily collected and identified from other worms and bivalves in the field. With the exception of A. ehlersi, the species investigated required minimal maintenance in the laboratory. Problems with A. ehlersi were associated with its collection and handling, as these polychaetes tended to drop their tails under stressful conditions. In addition, these species could not survive in the absence of sediment for burrowing and so could not be used for water-only tests. Of the four species, this species (at least for the adult life history stage that was tested), appears to be the least useful for development as a test species.

The acute toxicity tests and lethal endpoint used in this study indicated that all species were relatively insensitive to dissolved and sediment-bound copper and zinc. Chronic effects, such as reduced reproduction, or sub-lethal endpoints, such as avoidance of contaminated sediments or reduced burial rates, may occur at much lower concentrations and could be used as more sensitive indicators of toxicity for the test species used in this study. Roper and Hickey (1994) observed that burial rates of the bivalve Macomona liliana were reduced in sediments containing $15 \mu \mathrm{g} \mathrm{Cu} / \mathrm{g}$ DW and avoidance of copper contaminated sediments occurred 
1 at as little as $5 \mu \mathrm{g} \mathrm{Cu} / \mathrm{g} \mathrm{DW}$, while mortality was observed at $30 \mu \mathrm{g} \mathrm{Cu} / \mathrm{g} \mathrm{DW}$. This species is also sensitive

2 to zinc with reduced burial rates at $80 \mu \mathrm{g} \mathrm{Zn/g} \mathrm{DW} \mathrm{(Roper} \mathrm{et} \mathrm{al.} \mathrm{1995).} \mathrm{Behavioural} \mathrm{responses} \mathrm{of} \mathrm{some}$ organisms, such as increased activity in contaminated sediments, can lead to physico-chemical changes in sediments such as turbidity, and this has recently been used as an end-point in amphipod sediment tests. Turbidity was found to correlate with and be more sensitive than mortality (Briggs et al. 2003).

Apart from the toxicity of copper and zinc to T. deltoidalis and of copper to S. alba in sediment tests, no other evidence was observed for acute toxicity effects from sediment-bound metals. Low volumes of ingested sediment or low uptake (assimilation) of relatively insoluble contaminants from ingested sediments in the digestive system may contribute to the low exposure and the absence of acute toxic effects. The modes of toxicity for metals assimilated through gut uptake pathways (particulates) may also be quite different from those occurring due to uptake at gill or body surfaces (dissolved). The insensitivity of test organisms to sediment-bound metals, may also be due to characteristics of the sediment, which serve to reduce bioavailability of contaminants.

The bivalve T. deltoidalis was found to have the greatest potential as a test species for whole sediment toxicity tests. This species was the most sensitive to copper and zinc in water and sediment tests, through accumulation and/or lethal endpoints. It lives in direct contact with sediments through its feeding and behavioural habits, it is ecologically important, widely available and abundant throughout estuarine areas, and is easy to collect and handle. This species is tolerant to a wide range of abiotic factors including salinity and particle size, and hence could be used to test a wide range of sediment types. Further studies are recommended to investigate toxic effects from sediment-bound copper using sediments with a range of metal binding properties, and to test other chemicals to establish a toxicological database demonstrating this species sensitivity to a range of contaminants of concern in Australia (King et al. in prep). To increase the sensitivity of the test, a variety of sublethal endpoints and longer exposure periods should be investigated. Responses of this bivalve in whole-sediment toxicity tests should also be confirmed with responses of natural populations of benthic organisms. In addition, as exposure to sediment contaminants varies for species with differing behavioural and feeding habits (Wang and Fisher 1999), future work investigating other potentially suitable sediment-dwelling organisms such as amphipods that could be used in conjunction with the bivalve is currently underway (King et al. in prep).

\section{References}

31 ANZECC/ARMCANZ (2000) Australian and New Zealand guidelines for fresh and marine water quality.

32 Australia and New Zealand Environment and Conservation Council/Agricultural and Resource Management 
1 ASTM (1996). Standard Guide for Conducting Acute Toxicity Tests on Test Materials with Fishes,

2 Macroinvertebrates, and Amphibians. ASTM Designation: E729-96. American Society for Testing and

3 Materials, Philadelphia

4 ASTM (2002a) Standard guide for conducting 10-day static sediment toxicity tests with marine and estuarine

5 amphipods. ASTM Designation: E 1367-99. American Society for Testing and Materials, Philadelphia

6 ASTM (2002b) Standard guide for conducting sediment toxicity tests with marine and estuarine

7 polychaetous annelids. ASTM Designation: E 1611-00. American Society for Testing and Materials,

8 Philadelphia

9 ASTM (2002c) Standard guide for designing biological tests with sediments. ASTM Designation: E 1525-

10 02. American Society for Testing and Materials, Philadelphia

11 Batley GE, Burton GA, Chapman PM, Forbes VE (2002) Uncertainties in sediment quality weight-of12 evidence (WOE) assessments. Hum Ecol Risk Assess 8:1517-1547

Briggs AD, Greenwood N, Grant A (2003) Can turbidity caused by Corophium volutator (Pallas) activity be used to assess sediment toxicity rapidly? Mar Environ Res 55:181-192

Bryan GW (1976) Some aspects of heavy metal tolerance in aquatic organisms. In: Lockwood APM (ed) Effects of pollutants on aquatic organisms. Cambridge University Press, Cambridge, p 7-34

Bryan GW, Hummerstone LG (1973) Adaptation of the polychaete Nereis diversicolor to estuarine sediments containing high concentrations of zinc and cadmium. J Mar Biol Assoc U.K. 53:839-857

19 Chapman PM, Wang FY, Janssen C, Persoone G, Allen HE (1998) Ecotoxicology of metals in aquatic sediments: binding and release, bioavailability, risk assessment, and remediation. Can J Fish Aquatic Sci $55: 2221-2243$ Polychaeta. In: Beesley PL, Ross GJB, Glasby CJ (eds) Polychaetes and their allies: The Southern Synthesis. Fauna of Australia. Vol 4A: Polychaeta, Myzostomida, Pogonophora, Echiura, Sipuncula. CSIRO Publishing, Melbourne, p 1-296

Hall GEM (1997) Determination of trace elements in sediments. In: Mudroch A, Azcue JM, Mudroch P (eds) Manual of physico-chemical analysis of aquatic sediments. Lewis Publishers, New York, p 85-145 
1 Langston WJ, Spence SK (1995) Biological factors involved in metal concentration observed in aquatic

2 organisms. In: Tessier A, Turner DR (eds) Metal speciation and bioavailability in aquatic systems. John

3 Wiley and Sons, West Sussex, p 407-478

4 Luoma SN (1990) Processes affecting metal concentrations in estuarine and coastal marine sediments. In:

5 Rainbow PS, Furness RW (eds) Heavy Metals in the Marine Environment. CRC Press Inc, Florida, p 51-66

6 Mason AZ, Jenkins KD (1995) Metal detoxification in aquatic organisms. In: Tessier A, Turner DR (eds)

7 Metal speciation and bioavailability in aquatic systems. John Wiley and Sons, West Sussex, p 479-608

8 Miron G, Kristensen E (1993a) Factors influencing the distribution of nereid polychaetes: The sulfide aspect.

9 Mar Ecol Prog Ser 93:143-153

10 Miron G, Kristensen E (1993b). Behavioural response of three nereid polychaetes to injection of sulfide 11 inside burrows. Mar Ecol Prog Ser 101:147-155

12 Ponder WF (1998) Superfamily Galeommatoidea. In: Beesley PL, Ross GJB, Wells A (eds) Mollusca: The

13 Southern Synthesis. Fauna of Australia. Vol 5, Part B. CSIRO Publishing, Melbourne, p 316-318

14 Ponder WF, Clark SA, Dallwitz MJ (2000) Freshwater and estuarine molluscs: An interactive, illustrated key 15 for New South Wales. CSIRO Publishing, Victoria

16 Rainbow PS (1990) Heavy metal levels in marine invertebrates. In: Rainbow PS, Furness RW (eds) Heavy

17 Metals in the Marine Environment. CRC Press Inc, Florida, p 67-79

18 Reish DJ, Martin JM, Piltz FM, Word JQ (1976) The effect of heavy metals on laboratory populations of 19 polychaetes with comparison to water quality conditions and standards in Southern California marine waters.

20 Water Res 10:299-302

21 Riedel GF, Sanders JG, Osman RW (1997) Biogeochemical control on the flux of trace elements from 22 estuarine sediments: Water column oxygen concentrations and benthic infauna. Estuar Coastal Shelf Sci $23 \quad 44: 23-38$ Roper DS, Hickey, CW (1994) Behavioural responses of the marine bivalve Macomona liliana exposed to copper- and chlordane-dosed sediments. Mar Biol 118:673-680

Roper DS, Nipper MG, Hickey CW, Martin ML, Weatherhead MA (1995) Burial, crawling and drifting behaviour of the bivalve Macomona liliana in response to common sediment contaminants. Mar Poll Bull $31: 471-478$

Simpson SL (2001) A rapid screening method for acid-volatile sulfide in sediments. Environ Toxicol Chem 30 20:2657-2661 
1 Simpson SL, Rochford L, Birch GF (2002) Geochemical influences on metal partitioning in contaminated

2 estuarine sediments. Mar Freshwater Res 53:9-17

3 Simpson SL, Batley GE (2003) Disturbances to metal partitioning during toxicity testing Fe(II)-rich

4 estuarine pore waters and whole-sediments. Environ Toxicol Chem 22:424-432

5 Simpson SL, Roland MGE, Stauber JL, Batley GE (2003) Effect of declining toxicant concentrations on

6 algal bioassay endpoints. Environ Toxicol Chem, 22:2073-2079

7 Simpson SL, Angel BM, Jolley DF (2004) Metal equilibration in laboratory-contaminated (spiked)

8 sediments used for the development whole-sediment toxicity tests. Chemosphere, 54, 597-609.

9 Vismann B (1990) Sulfide detoxification and tolerance in Nereis (Hediste) diversicolor and Nereis

10 (Neanthes) virens (Annelida: Polychaeta). Mar Ecol Prog Ser 59:229-238

11 Wang WX (2002) Interactions of trace metals and different marine food chains. Mar Ecol Prog Ser 243:295-

12309

13 Wang WX, Fisher NS (1999) Delineating metal accumulation pathways for marine invertebrates. Sci Tot

14 Environ 237-238:459-472

15 Willan RC (1998) Superfamily Tellinoidea. In: Beesley PL, Ross GJB, Wells A (eds) Mollusca: The

16 Southern Synthesis. Fauna of Australia. Vol 5, Part B. CSIRO Publishing, Melbourne, p 342-348. 


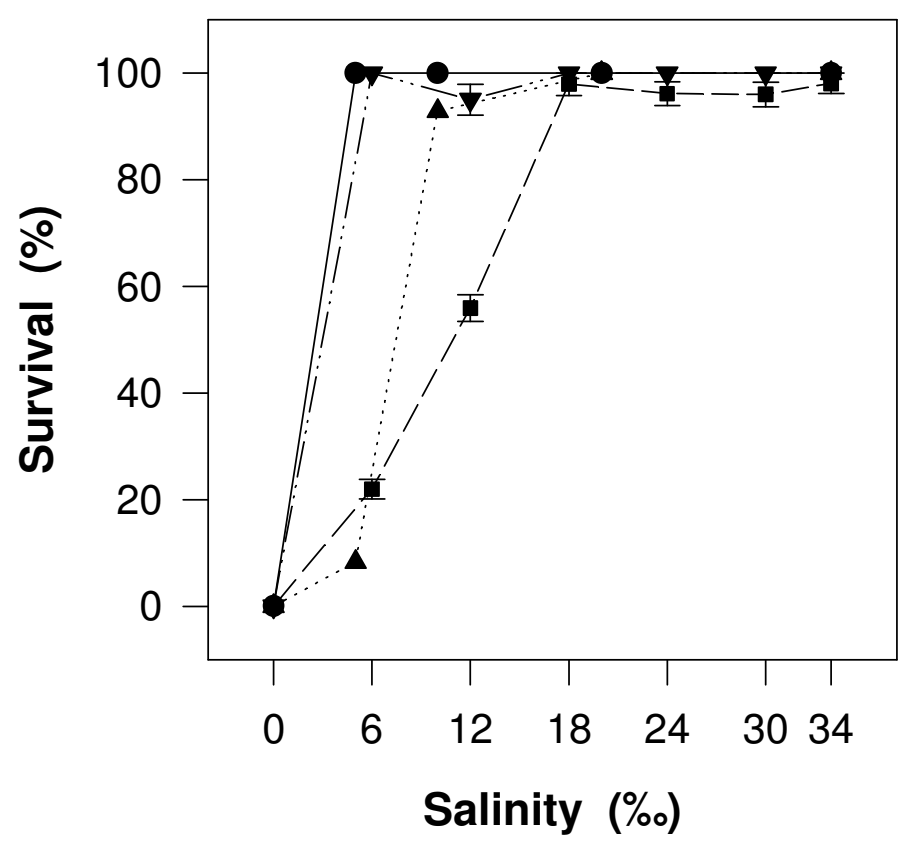

Fig. 1. The effect of salinity on the survival of the test species following $96 \mathrm{~h}$ exposure (mean \pm

4 SE; - Nephtys australiensis; - Mysella anomala; $\Delta$ Tellina deltoidalis; $\mathbf{\nabla}$ Soletellina alba). 

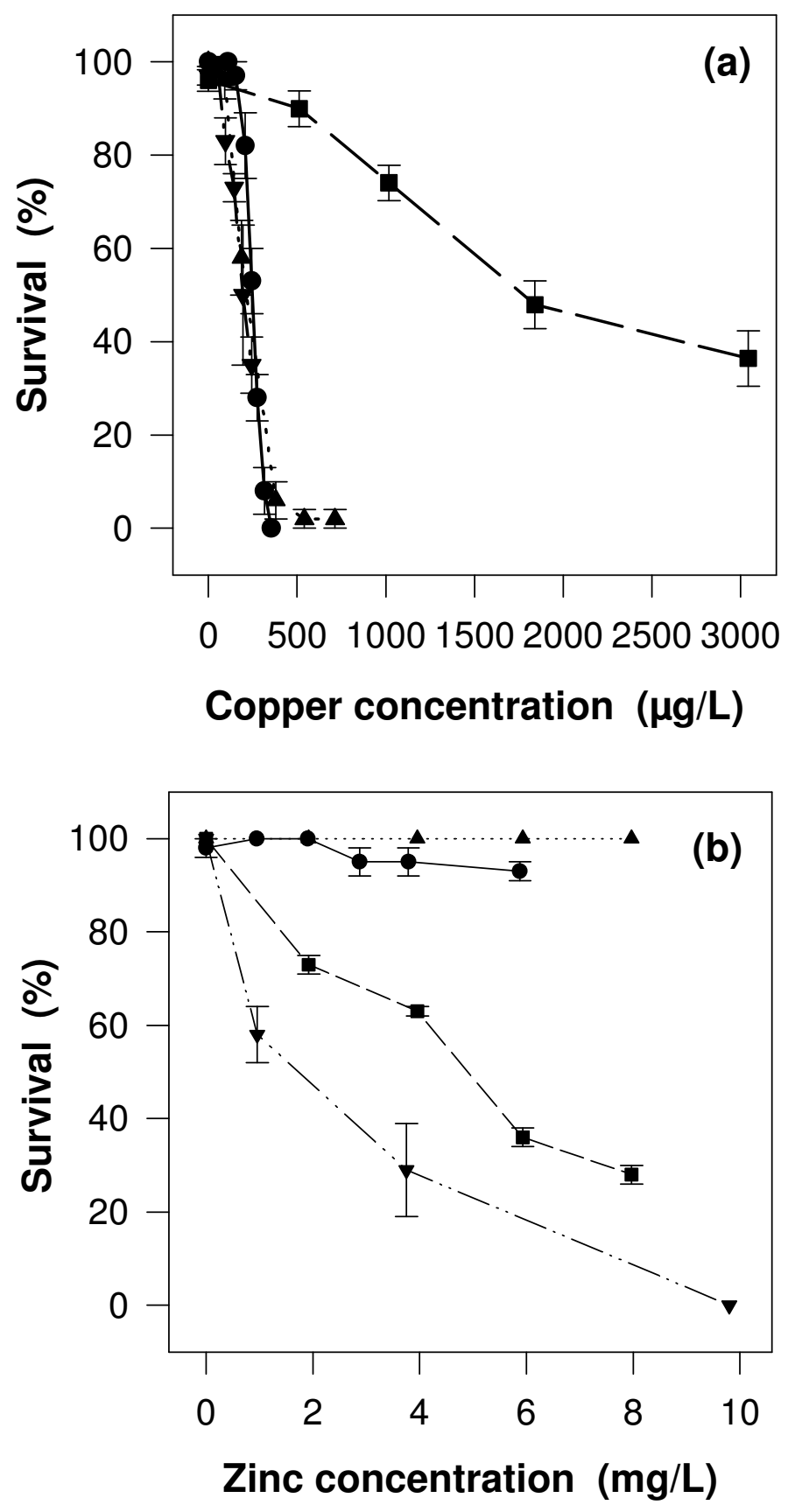

4

5 Fig. 2. The effect of aqueous a) copper and b) zinc on the survival of the test species following 96

6 h exposure (based on initial measured concentrations; mean \pm SE; • Nephtys australiensis;

$7 \quad$ Mysella anomala; $\Delta$ Tellina deltoidalis; $\mathbf{\nabla}$ Soletellina alba). 


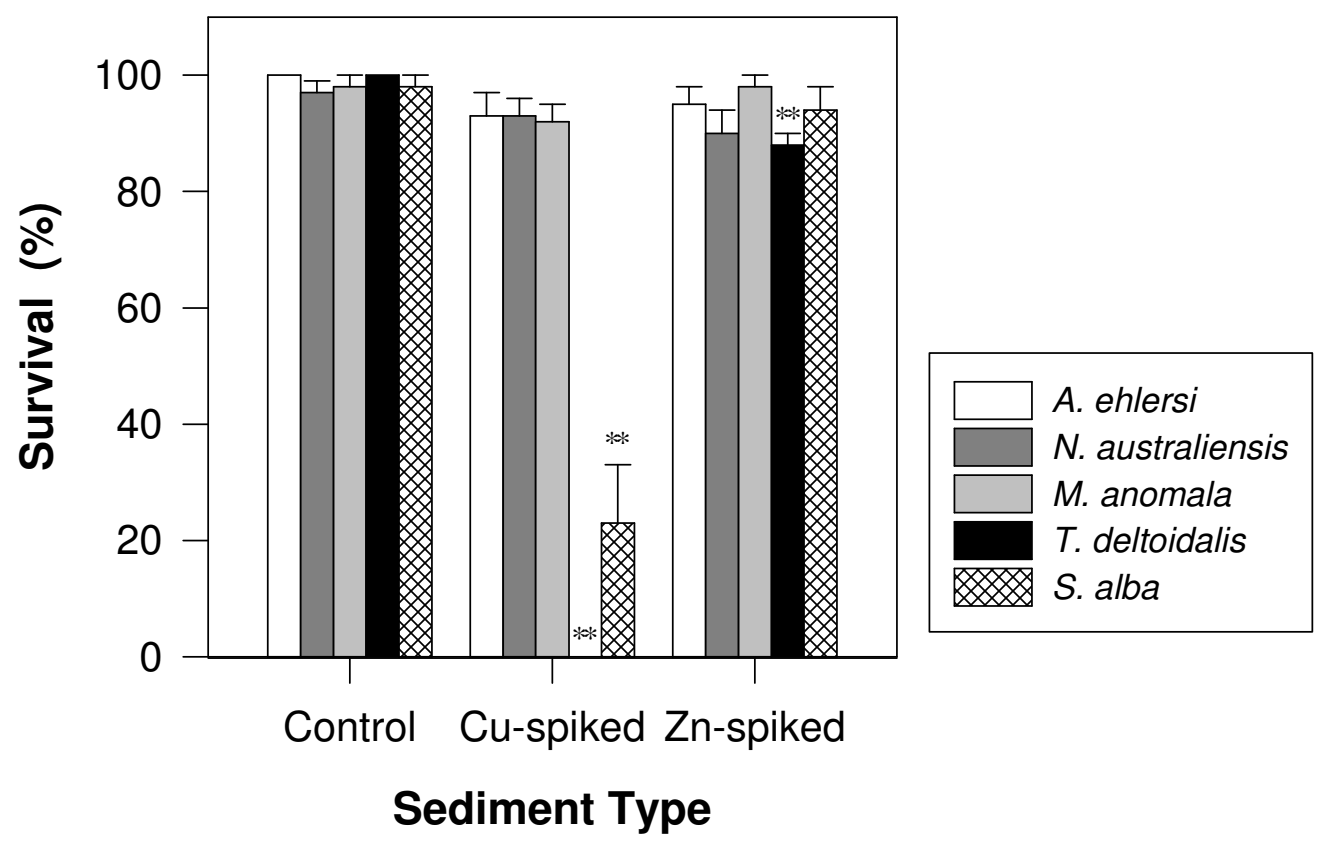

3

6 Fig. 3. The effect of sediment-bound copper and zinc on the survival of the test species following

$7 \quad 10 \mathrm{~d}$ exposure to spiked sediments (nominal total metal concentrations for copper- and zinc-spiked 8 sediments are 1300 and $4000 \mu \mathrm{g} / \mathrm{g}$ dry wt, respectively; mean $\pm \mathrm{SE} ; P<0.01$ indicated by $* *)$. 

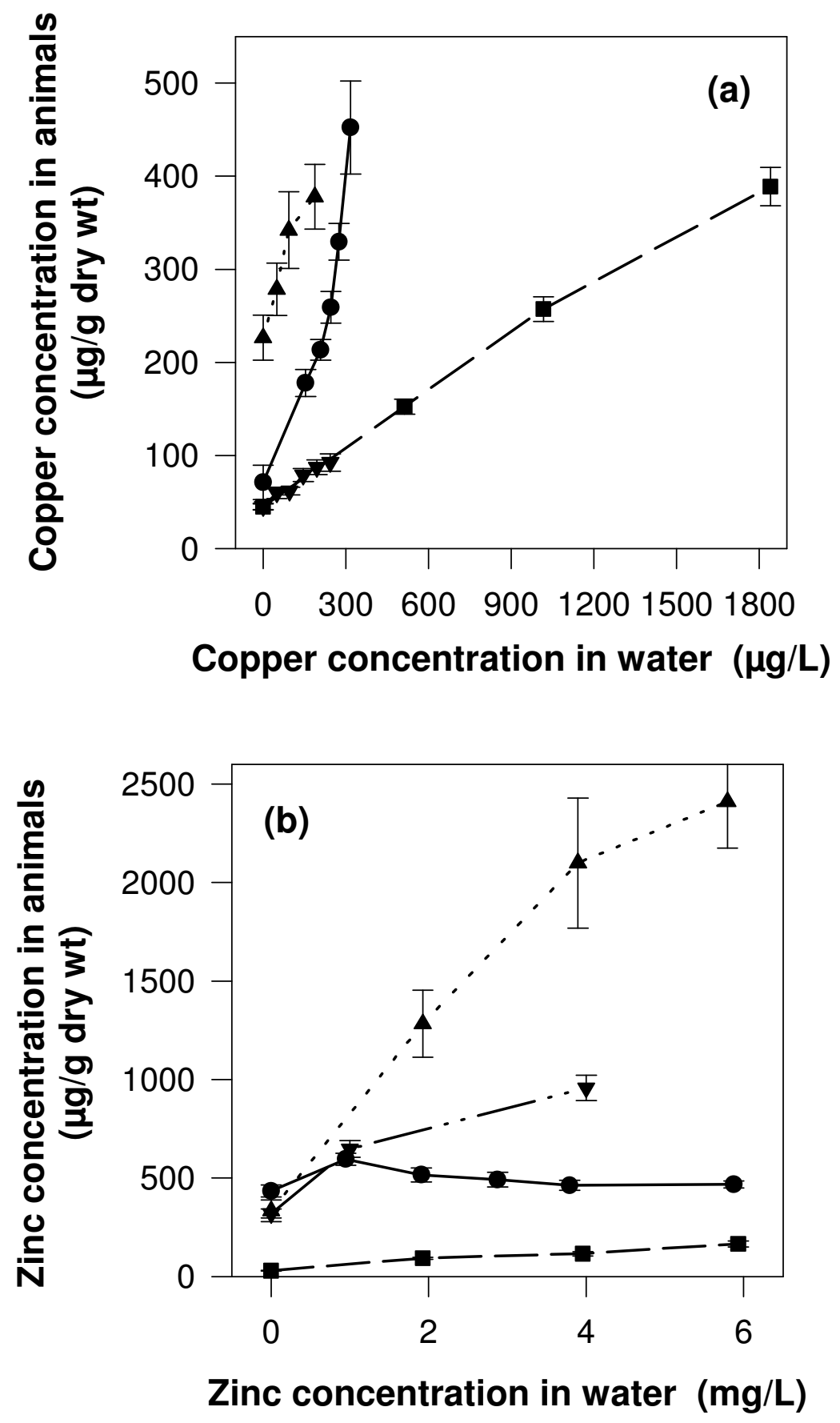

4 Fig. 4. Accumulation of a) copper and b) zinc in the tissues of the test species following $96 \mathrm{~h}$

5 aqueous exposure (mean $\pm \mathrm{SE} ; \bullet$ Nephtys australiensis; - Mysella anomala; $\boldsymbol{\Delta}$ Tellina deltoidalis; 6 จ Soletellina alba). 

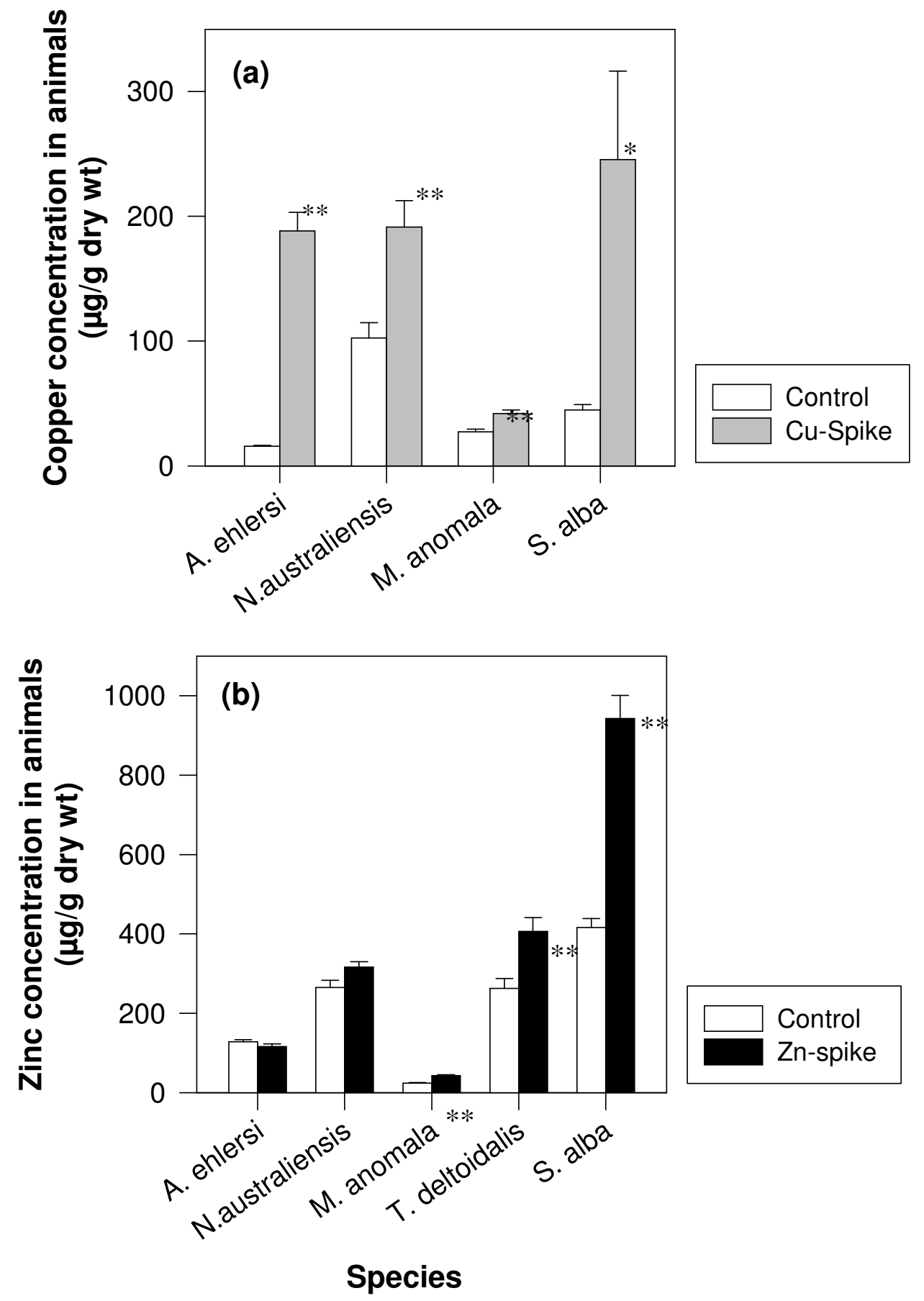

3 Fig. 5. Accumulation of a) copper and b) zinc in the tissues of the test species following 10-d

4 exposure to control and metal-spiked sediments (mean \pm SE; $P<0.01$ indicated by $* * ; P<0.05$ 5 indicated by *). 
1 Table 1. Acute toxicity data for 96-h water-only copper exposures

\begin{tabular}{lcccccc}
\hline Species & \multicolumn{2}{c}{ Copper, $\mu \mathrm{g} / \mathrm{L}(\mathrm{mean}$ data) } & \multicolumn{3}{c}{ Copper, $\mu \mathrm{\mu g} / \mathrm{L}$ (initial data) $^{\mathrm{b}}$} \\
\cline { 2 - 7 } & LC50 (95\% CL) & NOEC & LOEC & LC50 (95\% CL) & NOEC & LOEC \\
\hline Nephtys australiensis & $210(200-220)$ & 140 & 180 & $240(230-250)$ & 150 & 210 \\
Mysella anomala & $1500(1300-1800)$ & 480 & 900 & $2060(1640-2700)$ & 510 & 1000 \\
Tellina deltoidalis & $150(110-200)$ & 65 & 140 & $200(180-220)$ & 93 & 190 \\
Soletellina alba & $120(100-140)$ & 57 & 90 & $200(170-230)$ & 96 & 150
\end{tabular}

Effects concentrations calculated using, ${ }^{a}$ mean of measured initial and final, or ${ }^{b}$ initial measured dissolved copper concentrations.

5 Table 2. Acute toxicity data for 96-h water-only zinc exposures

\begin{tabular}{lcccccc}
\hline Species & \multicolumn{2}{c}{ Zinc, $\mu \mathrm{\mu g} / \mathrm{L}\left(\mathrm{mean}\right.$ data) $^{\mathrm{a}}$} & \multicolumn{3}{c}{ Zinc, $\mu \mathrm{\mu g} / \mathrm{L}\left(\right.$ initial data) $^{\mathrm{b}}$} \\
\cline { 2 - 7 } & LC50 $(95 \% \mathrm{CL})$ & NOEC & LOEC & LC50 $(95 \% \mathrm{CL})$ & NOEC & LOEC \\
\hline Nephtys australiensis & $>5800$ & 5800 & $>5800$ & $>5900$ & 5900 & $>5900$ \\
Mysella anomala & $4500(3800-5400)$ & $<200$ & 2000 & $4400(3700-5300)$ & $<1900$ & 1900 \\
Tellina deltoidalis & $>970$ & 970 & $>970$ & $>7900$ & 7900 & $>7900$ \\
Soletellina alba & $2900(2700-3100)$ & 1700 & 2300 & $4900(4600-5200)$ & 2000 & 3100
\end{tabular}

Effects concentrations calculated using, ${ }^{a}$ mean of measured initial and final, or ${ }^{b}$ initial measured dissolved copper concentrations.

9 Table 3. Metal concentrations in the test sediments, pore waters and overlying waters

\begin{tabular}{lcccccc}
\hline Species & \multicolumn{3}{c}{ Copper $^{\mathbf{a}}$} & \multicolumn{3}{c}{ Zinc $^{\mathbf{a}}$} \\
\cline { 2 - 7 } & $\begin{array}{c}\text { Sediment } \\
\boldsymbol{\mu g} / \mathbf{g}^{\mathbf{b}}\end{array}$ & $\begin{array}{c}\text { Pore water } \\
\boldsymbol{\mu g} / \mathbf{L}\end{array}$ & $\begin{array}{c}\text { Overlying } \\
\text { water, } \boldsymbol{\mu g} / \mathbf{L}\end{array}$ & $\begin{array}{c}\text { Sediment } \\
\boldsymbol{\mu g} / \mathbf{g}\end{array}$ & $\begin{array}{c}\text { Pore water } \\
\boldsymbol{\mu g} / \mathbf{L}\end{array}$ & $\begin{array}{c}\text { Overlying } \\
\mathbf{w a t e r}, \boldsymbol{\mu g} / \mathbf{L}\end{array}$ \\
\hline Australonereis ehlersi & 1300 & $22(38,7)$ & $70(11,130)$ & 3100 & $620(780,460)$ & $155(20,290)$ \\
Nephtys australiensis & 1400 & $49(12,86)$ & $50(5,95)$ & 3900 & $445(530,360)$ & $95(30,160)$ \\
Mysella anomala & 1200 & $22(21,23)$ & $40(7,73)$ & 3700 & $505(520,490)$ & $225(130,320)$ \\
Tellina deltoidalis & 1200 & $51(91,11)$ & $55(<3,130)$ & 3900 & $190(200,180)$ & $65(<3,130)$ \\
Soletellina alba & 1300 & $62(87,37)$ & $75(10,140)$ & 3950 & $590(490,690)$ & $270(70,470)$ \\
Control for all species & $40-50$ & $<3$ & $<3$ & $180-240$ & $<3-10$ & $20-30$ \\
\hline
\end{tabular}

$10{ }^{a}$ Concentrations are the mean of initial and final measured concentrations. Shown in parentheses are (initial, final)

11 concentrations. ${ }^{b}$ The initial and final sediment concentrations measured by $1-\mathrm{M} \mathrm{HCl}$ and aqua regia extraction were

12 within $10 \%$ of the mean value. 